\title{
Importance of Sustainability Performance Indicators as Perceived by the Users and Preparers
}

\author{
I-Hsiang (Hank) Lin ${ }^{1}$, Otto H. Chang ${ }^{2} \&$ Chunchia (Amy) Chang ${ }^{3}$ \\ ${ }^{1}$ International College, Xiamen University, China \\ ${ }^{2}$ Richard T. Doermer School of Business, Indiana University Purdue University Fort Wayne, Indiana, USA \\ ${ }^{3}$ College of Business, San Francisco State University, San Francisco, California, USA \\ Correspondence: ChunChia (Amy) Chang, College of Business, San Francisco State University, San Francisco, \\ CA 94132, USA. Tel: 1-415-405-0963. E-mail: amychang@sfsu.edu
}

Received: September 22, $2013 \quad$ Accepted: October 20, $2013 \quad$ Online Published: February 25, 2014

doi:10.5539/jms.v4n1p29 URL: http://dx.doi.org/10.5539/jms.v4n1p29

\begin{abstract}
Although sustainability reporting has shown significant advances in the past decade, research has not kept pace with these developments. Very few studies looked how stakeholders perceive the importance of sustainability reporting and disclosure. This paper explored how users and preparers rated the importance of performance indicators suggested by the Global Reporting Initiative (GRI) Guidelines regarding the environmental, economic and social impacts of a company. It provides evidence on which GRI performance indicators are perceived as relevant and important by both preparers and users. We found that users and preparers generally agree with the relevance and importance of all the performance indicators included in the GRI G3 guidelines. Despite a few areas of statistical disagreement, the overall perceptions were similar between users versus preparers regarding the importance of the GRI indicators. The convergence of the usefulness of GRI guidelines as viewed by the two conflicting stakeholders of users and preparers suggests that the stage may be ready for rule-making bodies and governmental agencies to further promote sustainability reporting by mandating uniform standards in reporting and disclosure.
\end{abstract}

Keywords: corporate sustainability, sustainability reporting, global reporting initiative

\section{Introduction}

Sustainability reporting has drawn interest from academia and practitioners for several decades. The interest started in the 1950s and proliferated in the 1970s (Carroll, 1999) with the initial interest focused on social reporting. In the 1980s, environmental reporting moved to the center stage due to rising awareness of environmental protection. Over the years, an increasing number of companies expanded their annual reports to cover social and environmental issues (Elkington, 1997; Waddock, 2002). Mandatory disclosure of environmental impacts was actually required in Denmark, Australia, France, Norway, Sweden, the Netherlands, the United Kingdom, and the United States (Scott, 2001; Jackson, 2005). During the 1990s and the 2000s, the concept of corporate social responsibility emerged. In 1997, Elkington developed the Triple Bottom Line (TBL hereafter) reports, which adds the reporting of economic impact in addition to environmental and social performance. In 2000, the three components were integrated into the Global Reporting Initiative (GRI hereafter) Framework and Reporting Guidelines. There were four versions of the Guidelines (G1-G4), and the most recent Guideline, G4, was introduced in April 2013.

The GRI Guidelines have slowly gained acceptance by companies for sustainability reporting. In 2010, GRI website listed 1,973 companies that adopted the GRI Guidelines in preparing their sustainability reports. Despite the popularity of GRI Guidelines, it was observed that preparers have different perceptions on the appropriate information needed in a sustainability report. Moreover, evidence also shows that users have different interpretations of the sustainability guidelines. Based on these observations, we saw a need for a study to explore how users and preparers perceive the relevance of GRI guidelines.

We surveyed users and preparers regarding their perspectives of GRI guidelines, in particular, the relevance and importance of the performance indicators suggested by the Guidelines. We investigated if there was a significant difference between users and preparers in their perception. We found that most of the GRI performance 
indicators were considered to be relevant and important by users and preparers and that there were no significant differences between users and preparers in their ratings of these indicators. The results indicate that there is high agreement between users and preparers regarding the relevance of GRI guidelines. This is encouraging because if there is consensus among the different stakeholders for the importance of the GRI report contents, the sustainability report may become an integral part of a company's annual report.

In the next section, we will review the literature regarding the GRI guidelines and the performance indicators. In Section 3, we will state our research questions and our hypotheses. In Section 4, our research methods are described. Section 5 presents our analyses and results. Finally, we provide a brief conclusion and state the limitations of the study.

\section{Literature Review}

\subsection{Sustainability Movement}

The social movement in the 1970s led to the emergence of social reporting. Social reporting documented the firm's effect on the social environment. It explains the resources utilized, shapes the signification or meaning underlying the firm language, and gives legitimacy to organizational action (Joseph, 2012; Giddens, 1984). Later, the social environment was included as one of the three dimensions in the sustainability reporting framework by Elkington (1997).

In the 1980s, the concern for environmental protection increased the importance of the environmental report, and social reporting started to incorporate the environmental report. Fichter et al. (1997) found the number of environmental reports had increased significantly over time and the "average quality" also improved. As a consequence, the environment reporting is factored into subsequent sustainability reports.

After the Brundtland Commission published the first volume of "Our Common Future" in 1987, the subject of corporate sustainability received greater attention.The Brundtland Commission suggested several implementation methods and it was credited with creating the most prevalent definition of sustainability. Although there has been ambiguity with the definition and the meaning of sustainability (Aras \& Crowther, 2009; Ortiz Martinez \& Crowther, 2005), an increasing number of companies have started to issue separate corporate sustainability reports (Moneva et al., 2007; Hardjono \& de Klein, 2004; Soerensen, 2003).

\subsection{Development of Sustainability Reporting and Disclosure}

In the 1990s, several researchers adopted Elkington's Triple Bottom Line (TBL) framework to define sustainability in three measurement dimensions: social, environmental, and economic performances (e.g., Ranganathan, 1998). This TBL framework developed by Elkington (1997) intends to capture a comprehensive set of values, issues, and processes that companies should address in order to minimize any harm and create positive benefits for society. Based on this framework, the Global Reporting Initiative (GRI) developed a set of guidelines and performance indicators for sustainability reporting.

The Global Reporting Initiative (GRI) was launched by the Coalition for Environmentally Responsible Economies [CERES], a Boston-based non-profit organization, and it aims to improve the "quality, rigor, and utility of sustainability reporting" (GRI, 2002). The Initiative was designed to create universal guidelines for voluntary sustainability reporting. The objective of GRI is to improve corporate accountability by ensuring that all stakeholders have access to standardized, comparable, and consistent environmental information akin to corporate financial reporting (Coalition for Environmentally Responsible Economies [CERES], 1997). Later, the United Nations Environment Programme joined in the endeavor to increase the legitimacy, funding resources, and administration of GRI. In 2002, GRI was incorporated into a non-profit organizationand relocated to Amsterdam.

GRI has published four versions of guidelines since 2000. The first generation (G1) and the second generation (G2) of the guidelines were published in 2000 and 2002, respectively. Implementation of G1 and G2 Guidelines raised some controversial issues regarding the performance indicators for economic, environmental, and social activities. The third generation (G3) Guidelines issued in 2006 applied a multi-stakeholder approach to increase the acceptance of performance indicators. Stakeholders included in the G3 deliberation were companies, non-governmental organizations, labor unions, accounting firms, investment institutions, and academia. In April 2013, Version 4 of the GRI Guidelines was released, and the social performance indicators were substantially expanded in detail and specification.Increasing numbers of corporations have voluntarily generated the annual sustainability report using the GRI Guidelines; however, the Guidelines are far from being universally accepted because of its voluntary nature. 


\subsection{Voluntarily Disclosure and Cost-Benefit Consideration}

Currently, not all corporations report sustainability performance because it is not required. The underlyinghope is that companies have incentives to disclose additional information to stakeholders to reduce the information asymmetry (Healy \& Palepu, 2001; Verrecchia, 1983). Thus, companies produce a voluntary report when the benefits of providing such a report outweigh the related costs, but there is a concern regarding the degree of truthfulness forvoluntary disclosure in sustainability reports. Previous research found that firms tend to mitigate the negative information and emphasize the positive information (Lindblom, 1994; Mahoney et al., 2009). In other words, sustainability reports became a tool for influencing stakeholders' perceptions on firm's operation. Without mandatory uniform criteria, firms can select favorable information to disclose regarding economic, environmental and social performance. This bias makes comparisons among sustainability reports difficult and it reduces the utility of sustainability reports. Before mandatory uniform criteria emerge, it is important to investigate how current voluntary criteria such as GRI are perceived by stakeholders. For example, are the GRI guidelines useful? Are the performance indicators suggested by GRI relevant and important? The answer to the first question was addressed in a separate paper by the authors. This study is an attempt to provide answers to the second question. We surveyed two primary groups of stakeholders of sustainability reports to provide empirical evidence on their perception of the GRI performance indicators. The result of our study might be helpful to the rule-making bodies and/or governmental agencies in their deliberation of mandatory sustainability reports. We develop our hypotheses in the next section.

\section{Research Questions and Hypotheses}

\subsection{Social Performance Indicators}

Social reporting was the first attempt to complement traditional financial reporting by measuring the social impactof corporate operations. Matthews (1997) reported that employment and product impacts were the two most targeted fields for the preparers of social reporting. Ranganathan (1998) identifies four key elements for social performance: (1) employment; (2) community relations; (3) ethical sourcing; and (4) social impact of products.

GRI Guidelines of 2006 (G3) lists four indicators for social performance: (1) labor practices, (2) human rights, (3) society, and (4) product responsibility. Each social performance indicator has sub-aspects. For labor practices, the five sub-indicators are employment, labor/management relationship, occupational health and safety, training and education, and diversity and equal opportunity. For human rights, the six sub-indicators are investment and procurement practice, non-discrimination, freedom of association, child labor, security practice, and indigenous rights. For society, the four sub-aspects are community, corruption, public policy, and anti-competitive behavior. For product responsibility, the four sub-aspects are customer health and safety, product and service labeling, marketing communications, and customer privacy.

Are these GRI social performance indicators equally relevant to the stakeholders? Do different stakeholders give different weights to the four social performance indicators? Kolk (2004) observed that health and safety (accident/injury frequency) seems to receive more weight among the social performance indicators. To answer these questions, we survey two of the stakeholder groups with conflicting interests: the preparers of the report and the users of the report. The first group has a tendency to choose what is easier to report and what will make the companies look more appealing. The second group has the incentive to look for information items that are most objective and relevant regardless of the preparation costs. We are interested in discovering (1) how each of the two stakeholders ranks the importance of social performance indicators and (2) if users and preparers rank social performance indicators differently. Since the two groups have conflicting interest in social performance reporting, we hypothesize that there is a difference in the perceived importance of the four social performance indicators: labor practices, human rights, society, and product responsibility. This leads to our first hypothesis.

HIa (in alternative form): There are differences in the perceived importance of the four GRI social performance indicators between users and preparers.

\subsection{Environmental Performance Indicators}

The awareness of environmental protection increased after a series of environmental accidents and ecological disasters in the 1970s and 1980s. Environmental reporting became a part of many sustainability reports. Currently, environmental disclosures are mandated in many countries, including the U.S. The federal legislation provides the Environmental Protection Agency (EPA) with the power to clean up waste sites and charge the clean-up costs to parties who it deems to be responsible for the contamination. In many industries, the cost to restore or clean up existing toxic sites can be significant. Thus, the SEC requires environmental disclosures to 
include any related future potential costs (Kieso et al., 2012).

Ranganathan (1998) suggested four key elements to measure environmental performance: material use, energy consumption, non-product output and pollutant release. The GRI G3 guidelines identify eight measurements for environmental performance. They are as follows: (1) materials; (2) energy; (3) water; (4) biodiversity; (5) emission, effluents, and waste; (6) products and services; (7) compliance; and (8) transport (GRI, 2006). Are these GRI environmental performance indicators equally relevant to the stakeholders? Do different stakeholders give different weights to the eight environmental performance indicators?

To answer these questions, we survey preparers and users on their perception. We were interested in understanding (1) how each of the two stakeholders ranks the importance of environmental performance indicators and (2) if users and preparers rank environmental performance indicators differently. With conflicting interests between the two groups in environmental performance reporting, we hypothesize that there is a difference in the perceived importance of the eight environmental performance indicators. Hence, our second hypothesis is stated in the alternative form as follows:

H2a: There are differences between users and preparers regarding the perceived importance of the 8 GRI environmental performance indicators.

\subsection{Economic Performance Indicators}

Economic performance in sustainability reports is frequently confused with the financial performance in accounting reports. The financial performance measures a company's profitability and future prosperity. On the other hand, economic performance in sustainability reports measures a company's influences on its stakeholders' economic circumstances and on the economic systems at local, national, and/or international levels (GRI, 2006). Because of such confusion, economic performance was frequently neglected and overlooked. This aspect of performance grew in popularity in the 1990s because of demand by users for sustainability reports. It was intended to measure flows of capital among different stakeholders and the economic impacts of the organization on the society (GRI, 2006).

GRI Guidelines (G3) lists three economic performance indicators: (1) economic performance; (2) market presence; and (3) indirect economic impacts. Similar to social and environmental performance indicators, each aspect contains a set of sub-indicators. How are these three indicators perceived by the stakeholders? Are they perceived differently by different stakeholders? We were unable to locate any literature on these questions. To provide initial data to answer these questions, we surveyed users and preparers regarding how they rank these three economic performance indicators and what differences exist among different stakeholders in the perceived importance of these indicators. Since the two groups have conflicting interest in the reports, we formulated the following hypothesis:

H3a (alternative): There are differences between users and preparers regarding the perceived importance of the three GRI economic performance indicators.

\section{Methodology}

This paper was an exploratory research designed to collect data on the users' and preparers' perceptions of sustainability performance indicators. Theoretically, in-depth interviews are the most effective approach for behavior researchers to gather attitudinal information, such as beliefs, behaviors, views and perceptions of individuals. We chose to conduct a survey instead of interviews after considering advantages of a survey method. A survey method is cost-effective, valid, easy to use, and time efficient to collect perception data as compared to the interview method (Billings \& Halstead, 2005).

\subsection{Sample Selection}

The subjects of this research were financial analysts and accountants who represent users and preparers of sustainability reports. Professionals working outside of the United States were excluded in the study. Accountants who were responsible for the preparation of sustainability reports for corporations were included in the preparer group. Financial analysts who use sustainability reports to analyze the performance of companies are selected into the user group.

\subsubsection{Sample for the Preparer Group}

The sample for the preparer group came from the following sources:

The Global Reporting Initiative (GRI) website. As of March 31, 2010, there are 155 firms listed in the GRI database; CorporateRegister.com. The website includes GRI based and non-GRI based sustainability reports worldwide. As of March 2010, the CorporateRegister.com listed 858 U.S. firms (including inactive firms) that 
currently issue or have ever issued sustainability reports in its database.

Our sample selection process for the preparer group started from the list on the GRI website. The data period ranges from 2007 to 2009 because GRI G3 guidelines were launched in October 2006. The objective of this research is to examine the perception of indicators included in the G3 Guidelines. Thus, all of the companies needed to have adopted these GRI Guidelines in the preparation of their sustainability reports to be included in our research. We also use the CorporateRegister.com to find firms who have issued sustainability reports following GRI Guidelines, but were not listed on the GRI website.

As the end, we included all the available firms listed by GRI and 45 firms from the CorporateRegistered.com database. The sample comprised of 39 industry sectors shown in Table 1. A total of 200 U.S. preparer companies were initially selected.

\subsubsection{Sample for the User Group}

Financial analysts represent users of sustainability reportsbecause they typically serve as asset managers of their investment portfolios. They have to factor in investees' governance policies and sustainability performance to make optimal decisions. We selected financial analysts from the following sources:

1) Financial advisors member list of the "Social Investment Forum" (SIF) which was renamed to The Forum for Sustainable and Responsible Investment (US SIF) in 2011. The US SIF is a nonprofit membership association consists of professionals, firms, institutions and organizations dedicating to enhance socially responsible investing.

2) Sustainable Investment Research Analyst Network (SIRAN). SIRAN is a branch of US SIF whose membership includes more than 220 North American sustainable investment research analysts from 35 investment firms, research providers, and affiliated investor groups.

3) Advisors list of the "First Affirmative Financial Network." First Affirmative Financial Network, LLC is formed by a group of financial advisor dedicated to serve socially conscious investors. Most financial advisors of the First Affirmative Financial Network have been a member of the US SIF. However, we found an additional 11 advisors from the First Affirmative Financial Network List for inclusion into the sample.

4) Advisors list of "Progressive Asset Management." This is a network which provides service of socially responsible investment. It is another network which provides service for socially responsible investment. More than half of its members are listed in the US SIF; however, we identified an additional 29 advisors from the list for inclusion.

We started the sample selection from the member list of the US SIF and its branch-SIRAN. Duplicate members were deleted. Since US SIF members include not only individuals but also firms, institutions and organizations, we expand our sample to include all the advisors from the firms, institutions and organizations in US SIF. Later, in an attempt to increase the diversity of our sample, two additional sources were included in our user group: financial analysts who were CFOs from B2BCFO.com (which has 162 members across the U.S.) and CFOwise.com (which has eight members mainly in the western states). These CFOs have accounting experience and/or backgrounds to analyze financial statements. The two websites were selected because of availability of contact information. A total of 590 users were initially selected.

\subsection{Instrument}

The instrument that we designed for the study contained questions such as "What environmental (social or economic) information should be included in a company's sustainability report?" The respondents were prompted with the performance indicators suggested by the GRI Guidelines. They were then asked to rate the importance of these indicators in a five-point Likert scale ranging from least important (coded as "1") to most important (coded as " 5 "). We use a five-point scale based on suggestions from prior literature (e.g., Litwin, 1995; Brace, 2004). An open-end space was provided so that subjects can fill in additional information or other indicators that they considered important. Finally, subjects were asked to provide background information such as their profession, industry, gender, age, education, and years of work experience.

We sent 200 copies of the questionnaire to U.S. firms which have issued sustainability report. For the user group, we sent out 590 questionnaires to financial analysts from our targeted sample. We received forty-five and forty-nine usable responses from preparers and users respectively. Therefore, a total of 94 cases were included in our statistical analyses.

\subsection{Analyses}

In addition to descriptive data, we employed a two-tailed $\mathrm{T}$ tests to see if there is a difference between users and 
preparers on the perceived importance of each GRI performance indicators. These indicators are grouped into three broad categories (social, environment, and economic) and within each category, there are multiple performance indicators that may correlate with each other. We therefore use a multivariate analysis to test if there is difference between users and preparers for each of the three broad categories by treating the performance indicators within that category as multivariate dependent variables. From the descriptive data, we found that the two groups of stakeholders differed significantly in their familiarity of GRI Guidelines. This difference might confound the result of our multivariate tests. We thus make the familiarity variable a covariate in our multivariate analyses to control the confounding effect of the familiarity factor.

To explore if the performance indicators can be collapsed into fewer dimensions within each of the three broad categories, we calculated the Cronbach Alpha statistics to ascertain if the subjects' responses reliably measured the same latent variable. Then, we conducted factor analysis to identify principal components from the subjects' responses. If the performance could be reduced to fewer measurements, we repeated our multivariate analysis using the factor scores generated from the factor analyses to see if the result changed.

\section{Results}

\subsection{Demographic Information}

Table 1 reports the industry distribution ofthe preparers. As shown in the table, the preparer group came from a wide variety of industries with a larger concentration in beverages, chemicals, electricity, and financial industries.

Table 1. Industry of preparers

\begin{tabular}{llll}
\hline Industry sector & Frequency & Industry sector & Frequency \\
\hline Aerospace \& Defense & 1 & Industrial Transportation & 0 \\
Automobile \& Parts & 0 & Leisure Goods & 2 \\
Banks & 1 & Life Insurance & 1 \\
Beverages & 3 & Media & 1 \\
Chemicals & 3 & Mining & 0 \\
Construction \& Materials & 0 & Mobile Telecommunications & 0 \\
Electricity & 3 & Nonequity Investment Instruments & 0 \\
Electronic \& Electrical Equipment & 1 & Nonlife Insurance & 0 \\
Equity Investment Instruments & 1 & Oil \& Gas Producers & 1 \\
Fixed Line Telecommunications & 0 & Oil Equipment, Services \& Distribution & 0 \\
Food \& Drug Retailers & 0 & Personal Goods & 2 \\
Food Products & 2 & Pharmaceuticals \& Biotechnology & 2 \\
Forestry \& Paper & 1 & Real Estate & 1 \\
Gas, Water \& Multiutilities & 0 & Software \& Computer Services & 1 \\
General Financial & 3 & Support Services & 2 \\
General Industrials & Technology Hardware \& Equipment & 2 \\
General Retailers & Tobacco & 1 \\
Health care Equipment \& Services & 2 & Travel \& Leisure & 1 \\
Household Goods & 0 & Total & $\mathbf{4 2}$ \\
Industrial Engineering & 0 & Unidentified & 3 \\
Industrial Metals & 0 & Grand Total & $\mathbf{4 5}$ \\
\hline
\end{tabular}

Table 2 displays the respondents' work experience. For both groups, the distribution was uneven with subjects who work less than 5 years and those who work for more than 20 years dominating the sample. 
Table 2. Work experiences of the respondents

\begin{tabular}{lll}
\hline & User & Preparer \\
\hline Less than 5 years & 19 & 11 \\
$6-10$ years & 12 & 10 \\
$11-15$ years & 5 & 5 \\
$16-20$ years & 0 & 4 \\
20 years and over & 13 & 15 \\
\hline Total & 49 & 45 \\
\hline
\end{tabular}

\subsection{Perceived Importance of GRI Performance Indicators}

\subsubsection{Social Performance Indicators}

GRI Guidelines lists five social performance indicators: (1) labor practices and decent work; (2) human rights; (3) society; (4) product responsibility; and (5) law and regulation compliance. Table 3 tabulates the perceived importance of the five performance indicators suggested by the GRI Guidelines. All of the mean values for these 5 indicators are nearly 4 or greater than 4 , indicating that most of these indicators are perceived to be important for social performance of a company. The two highest ranked indicators are product responsibility (customer health and safety; product and service labeling; marketing communications; customer privacy) and labor practices and decent work (employment; labor/management relationship; occupational health and safety; training and education; diversity and equal opportunity). The overall mean ratings for these two indicators are 4.27 and 4.17 respectively. The indicator ranked the last was the society indicator (community; corruption; public policy; anti-competitive behavior). The mean rating for this indicator is still a strong 3.94.

Users' ratings are higher than the preparers' in three aspects: human rights, labor practices, and product responsibility. In the human right and labor practices area, the differences are statistically significant at $\mathrm{p}=.01$ and $\mathrm{p}=.05$ respectively after controlling for the familiarity factor in the multivariate test. In the remaining two areas, law and society, the users' ratings are slightly lower than the preparers', but the differences are not statistically significant. In general, users and preparers did not differ greatly in their perception of the importance of the five social performance indicators.

Table 3. Perceived importance of social performance indicators

\begin{tabular}{|c|c|c|c|c|c|c|}
\hline \multirow{2}{*}{ Rank } & \multirow{2}{*}{ Performance Indicators } & \multicolumn{3}{|c|}{ Means } & \multirow{2}{*}{$\begin{array}{l}\text { Univariate } \\
\text { Test } \\
\mathrm{t} \text { value }\end{array}$} & \multirow{2}{*}{$\begin{array}{l}\text { Multivariate } \\
\text { Test } \\
\text { F value }\end{array}$} \\
\hline & & User & Preparer & Overall & & \\
\hline 1 & $\begin{array}{l}\text { Product responsibility (customer health and } \\
\text { safety; product and service labeling; } \\
\text { marketing communications; customer } \\
\text { privacy). }\end{array}$ & 4.29 & 4.24 & 4.27 & .337 & 0.543 \\
\hline 2 & $\begin{array}{l}\text { Labor practices and decent work } \\
\text { (employment; labor/management } \\
\text { relationship; occupational health and safety; } \\
\text { training and education; diversity and equal } \\
\text { opportunity). }\end{array}$ & 4.22 & 4.11 & 4.17 & .768 & $6.086^{*}$ \\
\hline 3 & $\begin{array}{l}\text { Human rights (investment and procurement } \\
\text { practice; non-discrimination; freedom of } \\
\text { association; child labor; security practice; } \\
\text { indigenous rights). }\end{array}$ & 4.18 & 4.02 & 4.11 & 1.018 & $7.143^{* *}$ \\
\hline 4 & Law and regulation compliance. & 4.00 & 4.04 & 4.02 & -.298 & 0.073 \\
\hline 5 & $\begin{array}{l}\text { Society (community; corruption; public } \\
\text { policy; anti-competitive behavior). }\end{array}$ & 3.90 & 3.98 & 3.94 & -.473 & 0.181 \\
\hline
\end{tabular}

*Significant at $\mathrm{p}=.05$ level.

To see if the five GRI social performance indicators share some common components based on the subjects' responses, we first calculated the Cronbach's alpha statistic of these responses to ascertain that these indicators reliably measured the same latent variables, then we performed a factor analysis on the responses to the five 
social indicators. The Cronbach's alpha coefficient was .843 for the five indicators. To assure all the indicators are relevant, we also verified that the coefficient did not increase as each individual indicator was removed. The factor analysis identified only one factor with Eigenvalue greater than one, explaining about $61 \%$ of the total variance. The factor loadings on this factor are reported in Table 4 below. The results indicate that the five social performance indicators sharing some commonality. Factor 1 thus can be interpreted as a composite measure of a company's social performance indicator. Using Factor 1 as the dependent variable, we perform a covariate analysis using familiarity with GRI Guidelines as the covariate. The F statistic is 2.902 (significant at 0.092 level), indicating a marginal difference between the users over the preparers on this composite indicator.

Table 4. Factor loading of social performance indicators

\begin{tabular}{lll}
\hline \multicolumn{2}{l}{ Social Performance Indicators } & Factor Loading \\
\cline { 3 - 3 } & & Factor 1 \\
\hline 1 & $\begin{array}{l}\text { Product responsibility (customer health and safety; product and service labeling; marketing } \\
\text { communications; customer privacy). }\end{array}$ & .781 \\
2 & $\begin{array}{l}\text { Labor practices and decent work (employment; labor/management relationship; occupational } \\
\text { health and safety; training and education; diversity and equal opportunity). }\end{array}$ & .830 \\
3 & $\begin{array}{l}\text { Human rights (investment and procurement practice; non-discrimination; freedom of } \\
\text { association; child labor; security practice; indigenous rights). }\end{array}$ & .826 \\
4 & $\begin{array}{l}\text { Law and regulation compliance. } \\
5\end{array}$ & Society (community; corruption; public policy; anti-competitive behavior). \\
\hline
\end{tabular}

\subsubsection{Environmental Performance Indicators}

Table 5 displays the perceived importance of the environmental performance indicators by users and preparers. Out of the eight suggested by the GRI Guidelines, the ratings of four indicators are close to or greater than the Likert scale of " 4 ," indicating "importance" of these indicators as perceived by the subjects in our study: energy (direct consumption; indirect consumption; energy saved due to conservation and efficiency improvements); emissions, effluents, and waste (total direct and indirect greenhouse gas emissions by weight; nitrogen oxide, sulfur oxide, and other significant air emissions by type and weight; total water discharged by quality and destination; total weight of waste by type and disposal method); water (total amount withdrawal; percentage and total volume of water recycled and reused); and products and services (initiatives to mitigate environmental impacts of products and services; percentage of products sold and their packaging materials that are reclaimed). The overall mean ratings are 4.27, 4.26, 4.06, and 3.99 respectively. The least ranked indicators are biodiversity, transportation, material usage, and regulation compliance. The overall mean ratings are 3.57, 3.69, 3.79, and 3.96 respectively.

In all eight environmental performance aspects suggested by GRI Guidelines, the ratings of users are always higher than the preparers. In two areas (biodiversity and emissions), the difference are statistically significant at .05 using univariate $t$ test or .01 using the multivariate test after controlling for familiarity factors. The significant difference between users and preparers may relate to the costs and controversies involved with measuring emissions and biodiversity. In general, preparers have the burden of collecting these sometimes ill-defined and controversial measurements. Therefore, there might be a tendency for them to discount these measurements because of the technical difficulty and costs associated with reporting these indicators. In comparison, users do not bear any burden of reporting these indicators and thus are more inclined to consider these disclosures important regardless of their production costs. 
Table 5. Perceived importance of environmental performance indicators

\begin{tabular}{|c|c|c|c|c|c|c|}
\hline \multirow{2}{*}{ Rank } & \multirow{2}{*}{ Performance Indicators } & \multicolumn{3}{|c|}{ Means } & $\begin{array}{l}\text { Univariate } \\
\text { Test }\end{array}$ & \multirow{2}{*}{$\begin{array}{l}\text { Multivariate } \\
\text { Test } \\
\text { F Value }\end{array}$} \\
\hline & & User & Preparer & Overall & t value & \\
\hline 1 & $\begin{array}{l}\text { Energy (direct consumption; indirect consumption; } \\
\text { energy saved due to conservation and efficiency } \\
\text { improvements). }\end{array}$ & 4.31 & 4.22 & 4.27 & .687 & 2.367 \\
\hline 2 & $\begin{array}{l}\text { Emissions, Effluents, and waste (total direct and } \\
\text { indirect greenhouse gas emissions by weight; NOx } \\
\text { (Nitrogen Oxide), SOx (Sulfur Oxide), and other } \\
\text { significant air emissions by type and weight; total } \\
\text { water discharged by quality and destination; total } \\
\text { weight of waste by type and disposal method). }\end{array}$ & 4.41 & 4.09 & 4.26 & $2.360 *$ & $7.205^{*}$ \\
\hline 3 & $\begin{array}{l}\text { Water (total amount withdrawal; percentage and } \\
\text { total volume of water recycled and reused). }\end{array}$ & 4.12 & 4.00 & 4.06 & .958 & 3.154 \\
\hline 4 & $\begin{array}{l}\text { Products and services (initiatives to mitigate } \\
\text { environmental impacts of products and services; } \\
\text { percentage of products sold and their packaging } \\
\text { materials that are reclaimed). }\end{array}$ & 4.00 & 3.98 & 3.99 & .161 & 0.610 \\
\hline 5 & $\begin{array}{l}\text { Regulation compliance (Monetary value of } \\
\text { significant fines and total number of non-monetary } \\
\text { sanctions for non-compliance with environmental } \\
\text { laws and regulations). }\end{array}$ & 4.08 & 3.82 & 3.96 & 1.636 & 2.347 \\
\hline 6 & $\begin{array}{l}\text { Material usage (by weight or volume; percentage of } \\
\text { materials used are from recycled materials). }\end{array}$ & 3.80 & 3.78 & 3.79 & .127 & 0.028 \\
\hline 7 & $\begin{array}{l}\text { Transportation (Significant environmental impacts } \\
\text { of transporting products). }\end{array}$ & 3.71 & 3.67 & 3.69 & .359 & 1.944 \\
\hline 8 & $\begin{array}{l}\text { Biodiversity of company sites (location and land of } \\
\text { company in protected areas; significant impacts of } \\
\text { activities, products, and services on biodiversity } \\
\text { inprotected areas; habitats protected or restored). }\end{array}$ & 3.76 & 3.38 & 3.57 & $2.393^{*}$ & $6.982 *$ \\
\hline
\end{tabular}

*Significant at $\mathrm{p}=.05$ level.

** Significant at $\mathrm{p}=.01$ level.

To see if the eight GRI environmental performance indicators share some common components based on the subjects' responses, we first calculated the Cronbach Alpha statistics for the eight indictors. The coefficient was registered at 0.810 , which is usually considered good for internal consistency. We also verified the relevance of these indicators by examining changes in the coefficient as indicators were deleted one by one. We then performed a factor analysis on the responses to the eight social indicators. The analysis identified two factors with Eigenvalue greater than one. The two factors combined explained about $62 \%$ of the total cumulative variance. The factor loadings on this factor are reported in Table 6 below. Factor 1 heavily loads on performance indicators measuring material usage, energy consumption, water recycling, biodiversity, emissions, and product impact on environment. It can be interpreted as a composite measure of a company's direct impact on environment from its operation. Factor 2 loads primarily on regulation compliance and transportation, and therefore is more related to the secondary measures of a company's environmental impact. Using both Factor 1 and Factor 2 as the dependent variables, we perform a multivariate analysis with familiarity of GRI Guidelines as the covariate. The F statistics are 2.057 and 4.570 respectively (significant at 0.155 and 0.032 respectively). This indicatesthe differences between the users and the preparers on Factor 1 scores were not statistically significant, but they were significantly different on the Factor 2 scores. 
Table 6. Perceived importance of environmental performance indicators

\begin{tabular}{|c|c|c|c|}
\hline \multicolumn{2}{|c|}{ Performance Indicators } & \multicolumn{2}{|c|}{ Factor Loading } \\
\hline 1 & $\begin{array}{l}\text { Energy (direct consumption; indirect consumption; energy saved due to } \\
\text { conservation and efficiency improvements). }\end{array}$ & $\begin{array}{l}\text { Factor } 1 \\
0.680\end{array}$ & $\begin{array}{l}\text { Factor } 2 \\
0.246\end{array}$ \\
\hline 2 & $\begin{array}{l}\text { Emissions, Effluents, and waste (total direct and indirect greenhouse gas } \\
\text { emissions by weight; NOx (Nitrogen Oxide), SOx (Sulfur Oxide), and other } \\
\text { significant air emissions by type and weight; total water discharged by quality } \\
\text { and destination; total weight of waste by type and disposal method). }\end{array}$ & 0.549 & 0.440 \\
\hline 3 & $\begin{array}{l}\text { Water (total amount withdrawal; percentage and total volume of water } \\
\text { recycled and reused). } \\
\text { Products and services (initiatives to mitigate environmental impacts of } \\
\text { products and services; percentage of products sold and their packaging } \\
\text { materials that are reclaimed). }\end{array}$ & 0.744 & 0.278 \\
\hline 4 & $\begin{array}{l}\text { Products and services (initiatives to mitigate environmental impacts of } \\
\text { products and services; percentage of products sold and their packaging } \\
\text { materials that are reclaimed). }\end{array}$ & 0.730 & 0.134 \\
\hline 5 & $\begin{array}{l}\text { Regulation compliance (Monetary value of significant fines and total number } \\
\text { of non-monetary sanctions for non-compliance with environmental laws and } \\
\text { regulations). }\end{array}$ & -0.029 & 0.870 \\
\hline 6 & $\begin{array}{l}\text { Material usage (by weight or volume; percentage of materials used are from } \\
\text { recycled materials). }\end{array}$ & 0.730 & -0.102 \\
\hline 7 & Transportation (Significant environmental impacts of transporting products). & 0.351 & 0.724 \\
\hline 8 & $\begin{array}{l}\text { Biodiversity of company sites (location and land of company in protected } \\
\text { areas; significant impacts of activities, products, and services on biodiversity } \\
\text { in protected areas; habitats protected or restored). }\end{array}$ & 0.553 & 0.370 \\
\hline
\end{tabular}

\subsubsection{Economic Performance Indicators}

Of the three economic performance indicators suggested by the GRI Guidelines, the highest rated indicator is economic performance (direct economic value generated and distributed to capital providers and governments; financial implications and other risks due to climate change; significant financial assistance received from government). The lowest rated indicator is indirect economic impact ("development and impact of infrastructure investments and services provided primarily for public benefit" and "understanding significant indirect economic impacts"). All the mean values of the three indicators are below the Likert scale of " 4 ", indicating that economic performance indicators are considered less important compared relatively to the social and environmental indicators. This may reflect the fact that economic aspect was the most recent addition to sustainability reporting and therefore it is less familiar to both the preparers and users.

Users' ratings are higher than preparers' in two areas: direct economic performance and indirect economic impacts. In the last remaining indicator, market presence, the mean rating of users were slightly lower than the preparers' (3.65 versus 3.67). All the differences are statistically insignificant, indicating that there is convergence in the perception of these economic performance indicators between users and preparers. 
Table 7. Perceived importance of economic performance indicators

\begin{tabular}{|c|c|c|c|c|c|c|}
\hline \multirow[t]{2}{*}{ Rank } & \multirow[t]{2}{*}{ Performance Indicators } & \multicolumn{3}{|c|}{ Means } & \multirow{2}{*}{$\begin{array}{l}\text { Univariate } \\
\text { Test } \\
\mathrm{t} \text { value }\end{array}$} & \multirow{2}{*}{$\begin{array}{l}\text { Multivariate } \\
\text { Test } \\
\text { F value }\end{array}$} \\
\hline & & User & Preparer & Overall & & \\
\hline 1 & $\begin{array}{l}\text { Economic performance (direct economic } \\
\text { value generated and distributed to capital } \\
\text { providers and governments; risks due to } \\
\text { climate change; significant financial } \\
\text { assistance received from government). }\end{array}$ & 4.00 & 3.84 & 3.93 & .890 & 2.630 \\
\hline 2 & $\begin{array}{l}\text { Market presence (localization) (policy, } \\
\text { practices, and proportion of spending on } \\
\text { locally-based suppliers; procedures for local } \\
\text { hiring). }\end{array}$ & 3.65 & 3.67 & 3.66 & -.092 & 0.023 \\
\hline 3 & $\begin{array}{l}\text { Indirect economic impacts (development and } \\
\text { impact of infrastructure investments and } \\
\text { services provided primarily for public } \\
\text { benefit; understanding significant indirect } \\
\text { economic impacts). }\end{array}$ & 3.45 & 3.31 & 3.38 & .746 & 3.475 \\
\hline
\end{tabular}

To see if the three GRI economic performance indicators share some common components based on the subjects' responses, we calculated the Cronbach alpha for the three indicators. The coefficient came out to be 0.587 , indicating low consistency among the three indicators. The Cronbach alphas if item deleted confirmed the low consistency. Despite of the reliability problem, we performed a factor analysis on the responses to the three economic indicators. The analysis identified only one factor with Eigenvalue greater than one, explaining about $55 \%$ of the total variance. The factor loadings on this factor are reported in Table 8 below. The results indicate that the three economic performance indicators share certain commonality. Factor 1 can thus be interpreted as a composite measure of a company's economic performance indicator. Using Factor 1 as the dependent variable, we perform a covariate analysis with familiarity of GRI Guidelines as the covariate. The F statistic is 2.575 (significant at 0.112 level), indicating that the difference between the users and the preparers on this composite indicator is not statistically significant.

Table 8. Factor loading of economic performance indicators

\begin{tabular}{|c|c|c|}
\hline \multicolumn{2}{|c|}{ Economic Performance Indicators } & \multirow{2}{*}{$\begin{array}{l}\text { Factor Loading } \\
\text { Factor } 1 \\
.633\end{array}$} \\
\hline 1 & $\begin{array}{l}\text { Economic performance (direct economic value generated and distributed to capital } \\
\text { providers and governments; financial implications and other risks due to climate change; } \\
\text { significant financial assistance received from government). }\end{array}$ & \\
\hline 2 & $\begin{array}{l}\text { Market presence (localization) (policy, practices, and proportion of spending on } \\
\text { suppliers; procedures for local hiring). } \\
\text { Suffolk University } \\
8 \text { Ashburton Place } \\
\text { Boston, MA } 02108 \text { su } \\
\text { locally-based }\end{array}$ & .771 \\
\hline 3 & $\begin{array}{l}\text { Indirect economic impacts (development and impact of infrastructure investments and } \\
\text { services provided primarily for public benefit; understanding significant indirect } \\
\text { economic impacts). }\end{array}$ & .811 \\
\hline
\end{tabular}

\section{Conclusion and Limitations}

\subsection{Conclusion}

In this study, we obtained evidence regarding the perceived importance of sustainability performance indicators suggested by the GRI Guidelines from two important stakeholder groups (preparers and users). We were motivated to conduct this research because few studies have been documented in this area of the literature. We found that users and preparers generally agree with the relevance and importance of all the performance 
indicators included in the GRI G3 guidelines. Despite a few areas of statistical disagreement, overall there were not strong differences in the perception of users versus preparers regarding the importance of the GRI indicators.

Our study contributes to sustainability reporting in a few ways. First, to our knowledge, our study is the first paper to examine both users' and preparer's perceptions of sustainability reporting. Prior research mainly focused on the preparers' perceptions or attitudes towards sustainability reports (Guthrie \& Parker, 1990; Kolk, 2004; Lindgreen et al., 2009; White, 2005). Second, our study extends the literature on GRI -- an area that few empirical observations have been accumulated. We surveyed how users and preparers rate the importance of performance indicators as suggested by the GRI Guidelines. It is one of the few studies that provide evidence on whether GRI based sustainability reports are perceived as desirable and relevant by stakeholders. Finally, by showing convergence of the usefulness of GRI guidelines as viewed by two conflicting stakeholders, we hope to have shown that the stage is ready for rule-makingbodies and governmental agencies to further promote sustainability reporting by mandating uniform standards in reporting and disclosure.

\subsection{Limitations and Suggestions for Future Research}

This research focused on two groups of stakeholders for sustainability reporting. While users and preparers are important stakeholders of the reports, there are other essential stakeholders such as general public and government regulators. Their perception of the reports will not necessarily coincide with the perceptions of preparers and users. Future research could easily focus on these other stakeholders to expand the horizon of sustainability research.

The sample in our study is limited to domestic subjects in the United States. While there might be shared perceptions among users and preparers in U.S. and other countries, the concept of sustainability and its interpretation is definitely contextually and culturally dependent. It is very likely that users and preparers from other countries might have very different views on the relevance of certain sustainability framework or guidelines. Future research can be conducted by involving subjects from different countries to ascertain the contextual and cultural influence on the perception.

Finally, the sustainability reporting framework we selected to study is the GRI G3 Guidelines. GRI G3 is only one of the several competing sustainability frameworks available for preparers to adopt. Other sustainability reporting framework such as United Nations Global Compact and ISO 26000 are also popular among corporate preparers and could be perceived to be more relevant and easier to implement by other stakeholders. Future research could conduct studies involving comparison of various sustainability reporting frameworks as perceived by certain stakeholders.

\section{References}

Aras, G., \& Crowther, D. (2009). Corporate sustainability reporting: a study in dis-ingenuity? Journal of Business Ethics, 87, 279-288. http://dx.doi.org/10.1007/s10551-008-9806-0

Billings, D. M., \& Halstead, J. A. (2005). Teaching in nursing: A guide for faculty (2nd ed.). St. Louis, MO: Elsevier Saunders.

Brace, I. (2004). Questionnaire design: how to plan, structure and write survey material for effective market research (2nd ed.). Market Research in Practice Series. London, England: Kogan Page.

Carroll, A. B. (1999). Corporate social responsibility: evolution of a definitional construct. Business \& Society, $38,268-295$.

Coalition of Environmentally Responsible Economies [CERES]. (1997). Global reporting initiatives concept paper. Unpublished working-paper. Boston, MA: Coalition of Environmentally Responsible Economies.

Elkington, J. (1997). Cannibals with Forks: The Triple Bottom Line of $21^{\text {st }}$ century business. London, England: Capstone.

Fichter, K., Loew, T., \& Seidel, E. (1997). Betriebliche Umweltkostenrechnung. Berlin, Germany: Springer. http://dx.doi.org/10.1007/978-3-642-59190-7

Giddens, A. (1984). The Constitution of society: Outline of the Theory of Structuration. Cambridge, England: Polity Press.

Global Reporting Initiative (GRI). (2002). Sustainability reporting guidelines. Boston, MA.

Global Reporting Initiative (GRI). (2006). Sustainability reporting guidelines. Amsterdam, Netherlands.

Hardjono, T., \& de Klein, P. (2004). Introduction on the European Corporate Sustainability Framework (ECSF). Journal of Business Ethics, 55(2), 99-113. http://dx.doi.org/10.1007/s10551-004-1894-x 
Healy, P., \& Palepu, K. (2001). A review of the empirical disclosure literature. Journal of Accounting \& Economic, 31(3), 441-456.

Jackson, R. (2005). An introduction to environmental and sustainability reporting. In C. S.Brown (Ed.), The Sustainable Enterprise: Profiting from Best Practice, 86-93. London, England: Kogan Page.

Joseph, G. (2012). Ambiguous but tethered: an accounting basis for sustainability reporting. Critical Perspectives on Accounting, 23(2), 93-106.

Kieso, D., Weygandt, J., \& Warfield, T. (2012). International Accounting (14th ed.). Hoboken, NJ: Wiley.

Kolk, A. (2004). Sustainability reporting. VBA Journal, 3, 34-42.

Lindblom, C. K. (1994). The implications of organizational legitimacy for corporate social performance and disclosure. Paper presented at the Critical Perspectives on Accounting Conference, New York, NY.

Lindgreen, A., Swane, V., \& Johnston, W. J. (2009). Corporate social responsibility: Anempirical investigation of U.S. organizations. Journal of Business Ethics, 85, 303-323. http://dx.doi.org/10.1007/s10551-008-9738-8

Litwin, M. S. (1995). How to measure survey reliability and validity. The Survey Kit (vol. 7). Thousand Oaks, CA: Sage Publications Inc.

Mahoney, L. S., Throne, L., La Gore, W. D., \& Cecil, L. (2009). Voluntary corporatesocial reporting signaling theory analysis. The American Accounting Association Annual Meeting, New York, August 2009.

Mattews, M. R. (1997). Twenty-five years of social and environmental accounting research: Is there a silver jubilee to celebrate? Accounting, Auditing \& Accountability Journal, 10(4), 481-531.

Moneva, J. M., Rivera-Lirio, J. M., \& Muñoz-Torres, M. J. (2007). The corporate stakeholder commitment and social and financial performance. Industrial Management \& Data Systems, 107(1), 84-102.

Ortiz Martinez, E., \& Crowther, D. (2005). Corporate social responsibility creates an environment for business success. In D. Crowther \& R. Jatana (Eds.), Representations of Social Responsibility (vol. 1, pp. 125-140). Hyderabad, India: ICFAIUniversity Press.

Ranganathan, J. (1998). Sustainability rulers: measuring corporate environmental and socialperformance. Sustainability Enterprise Perspective, May, 1-11. Washington, D.C.: World Resource Institute. Retrieved from www.igc.org/wri/meb/pdf/janet.pdf/

Scott, P. (2001). The pitfalls in mandatory reporting. Environmental Finance, April, 24-25.

Soerensen, P. (2003). Reporting sustainability. In A. Jolly (Ed.), OECD Economies and theWorld Today: Trends, Prospects, and OECD Statistics (pp. 133-135). London and Sterling, VA: Kogan Page.

Statement of Financial Accounting Concepts No. 5, FASB. (2008). Retrieved from http://www.fasb.org/cs/BlobServer?blobcol=urldata\&blobtable=MungoBlobs\&blobkey=id\&blobwhere=11 75820900391\&blobheader=application\%2Fpdf

Verecchia, R. E. (1983). Discretionary disclosure. Journal of Accounting \& Economics, 5, 179-194. http://dx.doi.org/10.1016/0165-4101(83)90011-3

Waddock, S. A. (2002). The multiple bottom lines of corporate citizenship: Social investing, reputation and responsibility audits. Business \& Society Review, 105(3), 323-45.

WCED (World Commission on Environment and Development). (1987). Our CommonFuture. Oxford, England: Oxford University Press.

White, G. B. (2005). How to report a company's sustainability activities. Management Accounting Quarterly, $7(1), 36-43$.

\section{Copyrights}

Copyright for this article is retained by the author(s), with first publication rights granted to the journal.

This is an open-access article distributed under the terms and conditions of the Creative Commons Attribution license (http://creativecommons.org/licenses/by/3.0/). 